\title{
Antioxidant Activity of Fruit Extracts of Prangos ferulacea (L.) Lindl. from Turkey
}

\author{
Cüneyt CESUR ${ }^{1}$, Belgin COŞGE ŞENKAL ${ }^{1}$, Cennet YAMAN ${ }^{1}$, Tansu USKUTOĞLU ${ }^{1}$, Murat KOÇ²
}

\begin{abstract}
It was aimed to determine anioxidant activity, and amount of total phenolic and flavonoid compounds of methanolic and ethanolic extracts of P. ferulaceae (L.) Lindl. fruits from Turkey. The fruits were collected at two different times, in May and July 2014. The total phenolic content of the extracts determined according to the Folin-Ciocalteu Reactifi (FCR) method was calculated as mg Gallic acid equivalent (GAE) $\mathrm{g}^{-1}$ extract. The total flavonoid content of the extracts was expressed as mg Quercetin $(\mathrm{QE}) \mathrm{g}^{-1}$ extract. The percentage of antioxidant activity of each samples was assessed by DPPH (2,2-diphenyl-1-picryl-hydrazyl-hydrate) free radical assay. Total phenolic and flavonoid contents of the extracts were determined to range from 11.750 to $79.111 \mathrm{mg} \mathrm{GAE} \mathrm{g}^{-1}$ extract and from 2.266 to $9.089 \mathrm{mg} \mathrm{QE} \mathrm{g}^{-1}$ extract, respectively. According to the results of DPPH test, all fruit extracts exhibited a slightly antioxidant activity.
\end{abstract}

Keywords: DPPH, Prangos ferulaceae, total flavonoid, total phenolic.

\section{Türkiye’deki Prangos ferulacea (L.) Lindl.’nin Meyve Özüitlerinin Antioksidan Aktivitesi}

ÖZET: Türkiye'de doğal olarak yetişen $P$. ferulacea (L.) Lindl.'in metanol ve etanol ile hazırlanan meyve özütlerinin toplam fenolik ve flavonoit miktarları ile antioksidan aktiviteleri belirlendi. Meyveler Mayıs ve Haziran 2014'de toplandı. Ekstraktların toplam fenolik içerikleri Folin-Ciocalteu Reactifi (FCR) yöntemine göre mg Gallik asit eşdeğeri (GAE) g ${ }^{-1}$ ekstrakt olarak hesaplandı. Ekstraktların toplam flavonoit içeriği mg Kuarsetin (QE) $\mathrm{g}^{-1}$ ekstrakt olarak ifade edildi. Her bir örneğin antioksidan aktivite yüzdesi DPPH (2,2-diphenyl-1-picryl-hydrazylhydrate) ile değerlendirildi. Özütlerin toplam fenolik ve flavonoit içerikleri sırasıyla 11.750-79.111 mg GAE g-1 ile 2.266-9.089 $\mathrm{mg} \mathrm{QE} \mathrm{g}^{-1}$ olarak belirlendi. DPPH testi sonuçlarına göre, tüm meyve özütlerinin zayıf antioksidan aktiviteye sahip olduğu tespit edildi.

Anahtar kelimeler: DPPH, Prangos ferulaceae , toplam fenolik, toplam flavonoit.

\footnotetext{
Cüneyt CESUR (0000-0002-1607-363X), Belgin COŞGE ŞENKAL(0000-0001-7330-8098), Cennet YAMAN (0000-0002-2364-8171), Tansu USKUTOĞLU(0000-0001-6631-1723), Bozok Üniversitesi Ziraat Fakültesi, Tarla Bitkileri Bölümü, Yozgat, Türkiye

Murat KOÇ(0000-0002-0829-4571), Bozok Üniversitesi, Hayvansal Üretim Yüksek Okulu, Yozgat, Türkiye

Sorumlu yazar/Corresponding Author: Belgin COŞGE ŞENKAL, bcosgesenkal@gmail.com
} 


\section{INTRODUCTION}

Prangos belonging to the Apiaceae family is a perennial genus. Turkey is an important center for this genus. The genus Prangos is represented by 21 taxa including 17 species ( $P$. acaulis, $P$. corymbosa, $P$. denticulata, $P$. ferulacea, $P$. heynia, $P$. hulusii, $P$. ilanae, $P$. meliocarpoides, $P$. pabularia, $P$. papillaris, $P$. peucedanifolia, $P$. platychlaena, $P$. acabra, $P$. scabrifolia, P. turcica, P. uechtritzii, and P. uloptera) 2 varieties ( $P$. meliocarpoides var. arcis-romanae and $P$. meliocarpoides var. meliocarpoides) and 2 subspecies (P.platychlaena subsp.engizekensis and P.platychlaena subsp. platychlaena) in the flora of Turkey, and 10 taxa of them are endemic. Prangos species are known as "çakşir otu" in Turkey (Guner et al., 2012). Prangos ferulaceae (L.) Lindl. is spread naturally in Northern and Southern Anatolia Regions of Turkey (Tubives, 2011)

This plant has been used as a medicinal plant in folk medicine of many countries in the world (KafashFarkhad et al., 2013). Especially, the extracts from the fruits and roots of the plant have been used for treatment several disorders such as digestive disorders, healing scars, and stop the bleeding. Also, essential oil is obtained from various parts of $P$. ferulaceae (L.) Lindl. such as leaves, flowers, fruits and stems. The previous studies on the essential oils of Prangos species showed variations from 0.2 to $1.1 \%$ in yield depending on the organs (Baser et al, 1996; Baser et al., 2000; Razavi et al., 2010). Thanks to their chemical compositions, essential oils have various biological activities (antifungal, antioxidant, antibacterial, etc.) (Mirzaei et al., 2007; Mneimne et al., 2016).

The free radicals that occur during normal body functions accelerate aging by damaging the cells and the immune system. Antioxidants bind the free radicals to themselves and inactivating them, they reduce the most possible damage and thus delaying aging. They play an important role in the prevention of human diseases (cancer, diabetes, dementia etc.) (Abdelhady et al., 2011; Shirazi et al., 2014). Nowadays, the organic and inorganic substances such as beta-carotene, C, E vitamins, lycopene, coenzyme, Q-10, selenium, zinc and manganese are the most widely used antioxidants. The vast majority of medicinal and aromatic plants that are rich in secondary metabolites have a strong antioxidant effect. In such plants, the antioxidant effect is usually related to the presence of phenols and flavonoids and their free radical scavenging activity (Baydar, 2013).

Phenolic compounds are generally colorless or colored, crystalline and amorphous substances which have a special odor and are well soluble in water, organic solvents (alcohol, ester, chloroform, ethyl acetate etc.), and bases liquid solutions. In recent years, these compounds have been studied extensively due to their potential to be protective against deadly diseases such as cancer and coronary heart diseases (Mammadov, 2014). Antioxidants are defined as compounds that prevent or delay oxidative degradation in food. It is known that oxygen is the most important factor in the degradation of many foodstuffs. It is only possible to delay or prevent the peroxidation process by addition of antioxidant compounds in foodstuffs. Butylated hydroxytoluene (BHT), butylated hydroxyanisole (BHA) and tertiary-butylhydroquinone (TBHQ) have been used as synthetic antioxidants to prevent degradation of foodstuffs for years. These synthetic antioxidants are phenolic compounds, which make them effective antioxidants (Abdelhady et al., 2011; Ogut, 2014). The use of BHA and BHT has been limited due to the fact that it causes liver damage and cancer in laboratory animals. For example, TBHQ is prohibited in the European Union countries, although it is free in the United States. For this reason, the demand for natural antioxidant resources is increasing day by day (Abdelhady et al. 2011; Mammadov 2014).

In this study, it is aimed to determine 2,2-diphenyl1-picrylhydrazyl (DPPH) radical scavenging activity, and amount of total phenolic and flavonoid compounds of the fruit extracts from P. ferulaceae (L.) Lindl. growing naturally in Turkey.

\section{MATERIAL AND METHODS}

\section{Plant material}

The fruits of $P$. ferulacea were collected at two different times at an altitude of $1420 \mathrm{~m}$ from the area between Tunceli and Pülümür located to the east of Turkey $\left(39^{\circ} 28^{\prime} 20^{\prime \prime} \mathrm{N}, 039^{\circ} 54^{\prime} 25^{\prime \prime} \mathrm{E}\right)$. The first and second collection was held in May and July 2014, 
respectively. The plant samples numerated as M. Koç. 1334 were deposited at the Herbarium of the Bozok University Department of Biology (Yozgat/ Turkey).

\section{Solvent extraction}

Collected fruits were dried in the shade and ground with a blender. The samples were prepared with three replications for each of the two collection times. 40 $\mathrm{mL}$ of methanol was added to $4 \mathrm{~g}$ of sample, and these samples were kept in the oven at $40{ }^{\circ} \mathrm{C}$ for $24 \mathrm{~h}$. The solutions obtained were centrifuged at $4500 \mathrm{rpm}$ for $10 \mathrm{~min}$. Supernatant fractions of the solutions were removed and the organic solvent was separated by using a rotary evaporator. The extracts were stored in the dark at $4{ }^{\circ} \mathrm{C}$ until used.

\section{Determination of total phenolic compounds}

The total phenolic content of the extracts was determined according to the Folin-Ciocalteu Reactifi (FCR) method (Singleton et al., 1999). $0.2 \mathrm{ml}$ was taken from the sample solutions prepared with ethanol and methanol $\left(2 \mathrm{mg} \mathrm{ml}^{-1}\right)$ and distilled water was added. Then $0.2 \mathrm{ml}$ of Folin-Ciocalteu was added to this solution, and allowed to stand for $3 \mathrm{~min} .0 .6 \mathrm{ml}$ of $\mathrm{Na}_{2} \mathrm{CO}_{3}(20 \%)$ was added on this solution, and the total volume was adjusted to be $10 \mathrm{ml}$. The obtained solution was incubated in the dark for 2 hours, and then absorbance measurements were made at $760 \mathrm{~nm}$. Gallic acid was used to form the standard calibration curve. $0.2 \mathrm{ml}$ of ethanol was added to each test tube. $0.1 \mathrm{mg} / \mathrm{ml}$ was prepared as the main stock from Gallic acid. Ethanol was added to the sample solution $(0.2 \mathrm{ml})$ for the control. According to the Gallic acid standard graph, the total phenolic substance in all plant extracts was calculated as $\mathrm{mg}$ Gallic acid equivalent (GAE) $\mathrm{g}^{-1}$ extract.

\section{Determination of total flavonoid compounds}

The total flavonoid contents of the extracts were determined by adapting the Arvouet-Grand et al. (1994) method. $8 \mathrm{mg} \mathrm{ml}^{-1}$ from extract solution dissolved in ethanol and methanol was prepared as the main stock. $100 \mu \mathrm{L}$ of $10 \%$ aluminum nitrate and $100 \mu \mathrm{L}$ of $1 \mathrm{M}$ potassium acetate were added to $250 \mu \mathrm{L}$ of the sample. The final volume of the solution was $5 \mathrm{ml}$ with $99 \%$ ethanol. Absorbance measurements were made at 417 $\mathrm{nm}$ after incubation at room temperature for 40 minutes in the dark. $0.5 \mathrm{mg} \mathrm{ml}^{-1}$ was prepared as the main stock for the Quercetin standard. The total flavonoid content of the extracts was expressed as mg Quercetin (QE) $\mathrm{g}^{-1}$ extract. To determine the total phenolic and flavonoid contents of the extracts, spectrophotometric measurements were performed using a Perkin Elmer Lambda 25 UV/VIS spectrometer.

\section{Free radical scavenging activity by DPPH method}

The percentage of antioxidant activity (AA \%) of each samples was assessed by DPPH (2,2-diphenyl1-picryl-hydrazyl-hydrate) free radical assay. The measurement of the DPPH radical scavenging activity was performed according to methodology described by Gezer et al. (2006). $4 \mathrm{mg}$ DPPH was added to 100 $\mathrm{mL}$ of the solvent (methanol/ethanol) to prepare the concentration. The extracts dissolved in methanol and ethanol was used in this study. $8 \mathrm{mg} \mathrm{mL}^{-1}$ extract solutions were prepared as the main stock, and the dilutions were obtained at different concentrations (100, $200,400,600,800$, and $1000 \mu \mathrm{g} \mathrm{mL}^{-1}$ ) from this stock. $200 \mu \mathrm{L}$ of extract solutions in different concentrations were added into $3.2 \mathrm{~mL}$ of DPPH solution. The solvent amounts in each test tube were set to be $200 \mu \mathrm{L}$ of ethanol and $3.2 \mathrm{~mL}$ methanol. The absorbance at 517 $\mathrm{nm}$ was recorded after $30 \mathrm{~min}$ of incubation at room temperature in dark using a Perkin Elmer Lambda 25 UV/VIS spectrophotometer. Ascorbic acid was used as standard antioxidant. The scavenging activity percentage of each sample was determined according to the following equation: $\mathrm{AA}(\%)=100-\left[\left(\mathrm{A}_{\text {control }}-\mathrm{A}\right.\right.$ sample $\left.) / A_{\text {control }} \times 100\right]$

where $\mathrm{A}_{\text {control }}$ is the absorbance of the control with methanol and $\mathrm{A}_{\text {sample }}$ is the absorbance of essential oils and plant extracts.

\section{Statistical analysis}

Experiments were performed in three replicates and two parallel for each replicate. The results were expressed as \pm SD. Data obtained were subjected to analyses of variance (ANOVA) and correlation analysis using TARIST statistical program. Means were separated at $\alpha=0.05$ probability level by the LSD (the least significant difference) test (Acikgoz et al., 2004). 


\section{RESULTS AND DISCUSSION}

The yield (g) of fruits extracts were $0.4784 \pm 0.182$ in the first collection in May and
$0.1896 \pm 0.064$ in the second collection in July. Total phenolic and flavonoid contents in the fruit extracts of $P$. ferulaceae given in Table 1.

Table 1. Total phenolic and flavonoid contents in the fruit extracts of P.ferulaceae

\begin{tabular}{lll}
\hline Extract Types & $\begin{array}{l}\text { Total phenolic content } \\
\left(\mathbf{m g ~ G A E} \mathbf{g}^{-1} \text { extract }\right)\end{array}$ & $\begin{array}{l}\text { Total flavonoid content } \\
\left(\mathbf{m g ~ Q E ~} \mathbf{~ g}^{-1} \text { extract }\right)\end{array}$ \\
\hline M1 & $11.750 \pm 0.3472 \mathrm{c}^{*}$ & $2.266 \pm 1.646 \mathrm{~b}$ \\
M2 & $12.965 \pm 1.7010 \mathrm{c}$ & $3.359 \pm 1.220 \mathrm{~b}$ \\
E1 & $79.111 \pm 2.6820 \mathrm{a}$ & $9.089 \pm 2.482 \mathrm{a}$ \\
E2 & $67.479 \pm 1.4456 \mathrm{~b}$ & $3.203 \pm 0.004 \mathrm{~b}$ \\
\hline
\end{tabular}

*Each value is the average of three analyses \pm standard deviation. The same letter do not differ significantly at $p<0.05$.

M1: Methanolic extract, first collection; M2: Methanolic extract, second collection; E1: Ethanolic extract, first collection; E2: Ethanolic extract, second collection

Methanol and ethanol extracts of fruits obtained from the first and second collection were standardized for their contents of phenolic compounds. The calibration curve showed linearity for Gallic acid in the range of 20-100 $\mu \mathrm{g} \mathrm{ml}^{-1}$, with a correlation coefficient $\left(\mathrm{R}^{2}\right)$ of 0.999 (Figure 1). The results of the total phenolic content determination of the fruit extracts obtained from the first and second collection, used two different solvents (methanol and ethanol) are given in Table 1. E1 contained the highest content of phenolic (79.111 mg GAE $\left.\mathrm{g}^{-1}\right)$, followed by E2 (67.479 $\left.\mathrm{mg} \mathrm{GAE}^{-1}\right)$, M2 (12.965 $\left.\mathrm{mg} \mathrm{GAE} \mathrm{g}^{-1}\right)$ and M1 (11.750 $\left.\mathrm{mg} \mathrm{GAE} \mathrm{g}^{-1}\right)$. Ethanolic extracts contained higher levels of phenolic than methanolic extracts in our study.

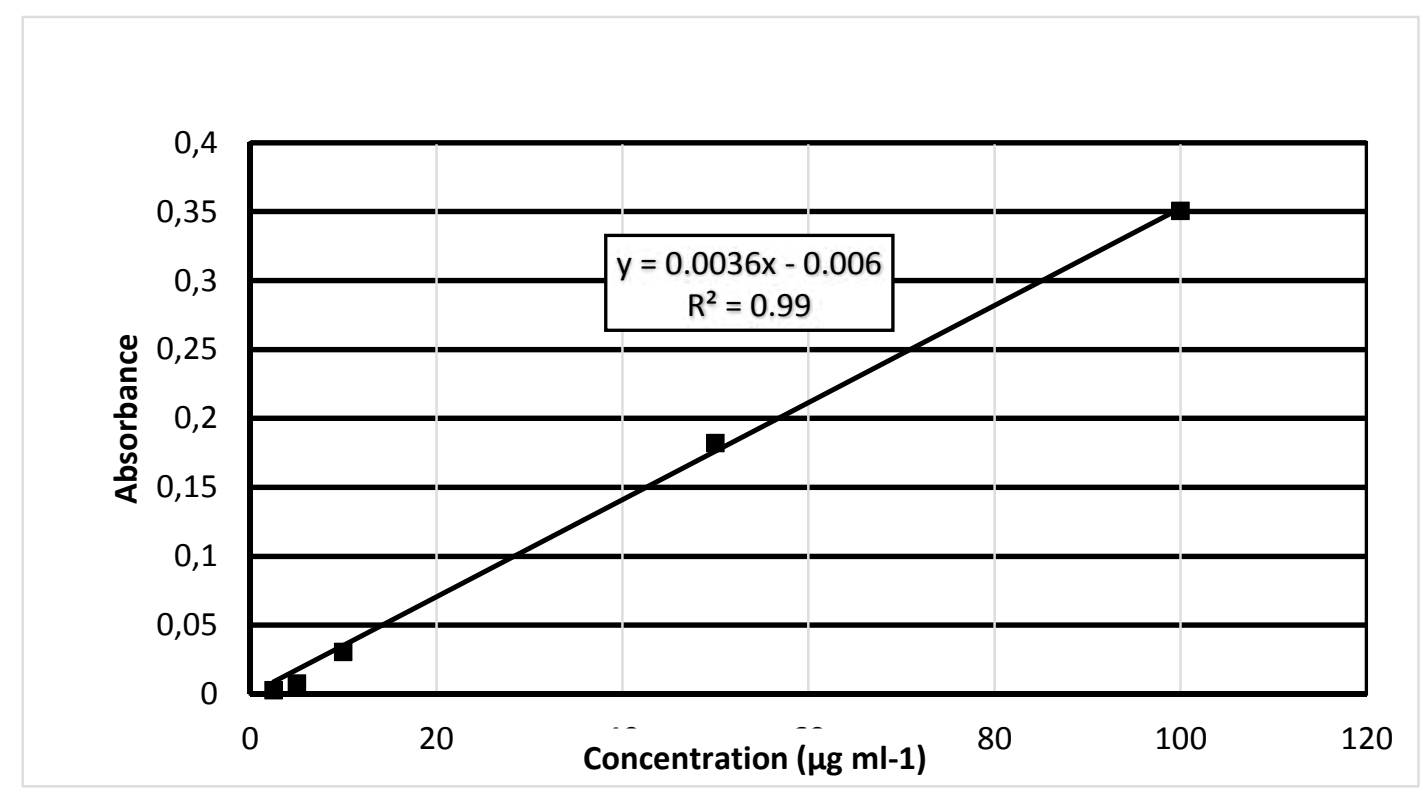

Figure 1. Standard calibration curve of gallic acid at concentration of 20,40,60, 80 and $100 \mu \mathrm{g} \mathrm{ml}^{-1}$. Spectrophotometric detection was at $760 \mathrm{~nm}$

The calibration curve showed linearity for Quercetin in the range of 100-600 $\mu \mathrm{g} \mathrm{ml}^{-1}$, with a correlation coefficient $\left(\mathrm{R}^{2}\right)$ of 0.9974 (Figure 2). 


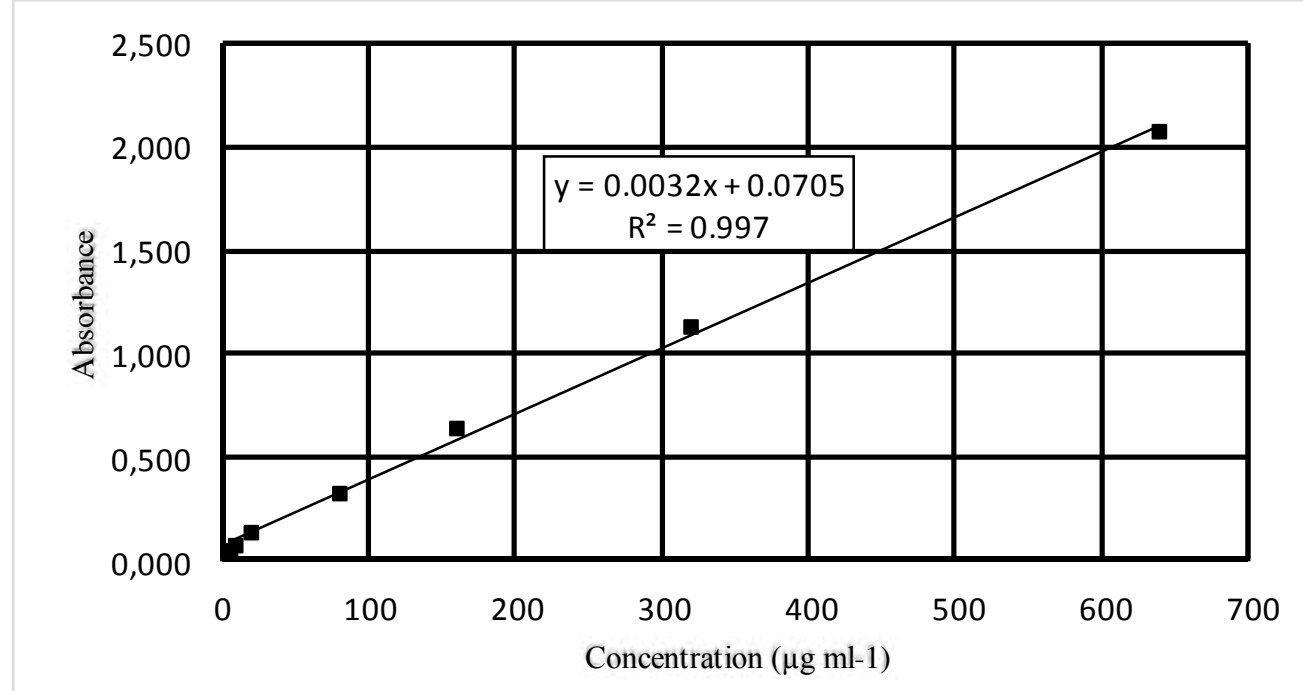

Figure 2. Standard calibration curve of Quercetin at concentration of 100, 200, 300, 400, 500 and $600 \mu \mathrm{g} \mathrm{ml}^{-1}$. Spectrophotometric detection was at $417 \mathrm{~nm}$

Total flavonoid content in fruit extracts ranged from 2.266 (M1) to 9.089 (E1) $\mathrm{mg}$ QE/g extract. The ethanol extract of fruits obtained from first collection showed the highest amounts of flavonoid content than the other examined extracts (Table 1). DPPH, a stable free radical, radical scavenging activity is a very popular method used in screening the antioxidant activity of plant extract (Tirzitis and Bartosz, 2010). The Table 2 is given the antioxidant activities of ethanol and methanol extracts of fruit examined using the DPPH radical scavenging recorded in terms of $\%$ inhibition. Higher $\%$ inhibition value means better scavenging activity/antioxidant potential. The results obtained were compared with the standard AA (Figure 3). The extracts prepared with methanol exhibit higher DPPH scavenging activity those prepared with ethanol. The antioxidant potential of the fruits collected in May (6.4$80.3 \%$ ) was found to be higher than those collected in July (4.4-70.1\%). According to the values in Table 2, E2 in $100 \mu \mathrm{g} / \mathrm{ml}$ has minimum DPPH scavenging activity (4.4\%) and $\mathrm{M} 1$ in $1000 \mu \mathrm{g} / \mathrm{ml}$ has maximum DPPH scavenging activity $(80.3 \%)$ among fruits extracts and M1 has shown better DPPH scavenging activity as compared to the other extracts.

Table 2. Free radical scavenging activity of P. ferulacea fruit extracts by DPPH methods (\%)

\begin{tabular}{|c|c|c|c|c|c|c|}
\hline $\begin{array}{l}C^{1} \\
\left(\mu g \mathbf{m L}^{-1}\right)\end{array}$ & M1 & M2 & E1 & E2 & $\begin{array}{l}\mathrm{C} \\
\left(\mu \mathrm{g} \mathrm{mL}^{-1}\right)\end{array}$ & $\mathbf{A A}$ \\
\hline 100 & $6.4 \pm 0.058 \mathrm{a}^{2}$ & $5.4 \pm 1.950 \mathrm{ab}$ & $6.5 \pm 2.252 \mathrm{a}$ & $4.4 \pm 0.400 \mathrm{~b}$ & 10 & $4.00 \pm 0.672$ \\
\hline 200 & $15.0 \pm 1.000 \mathrm{a}$ & $13.1 \pm 1.100 \mathrm{~b}$ & $10.9 \pm 0.351 \mathrm{c}$ & $7.8 \pm 0.600 \mathrm{~d}$ & 20 & $11.23 \pm 1.040$ \\
\hline 400 & $33.0 \pm 1.650 \mathrm{a}$ & $29.8 \pm 2.000 \mathrm{~b}$ & $19.0 \pm 0.058 \mathrm{c}$ & $15.0 \pm 1.050 \mathrm{~d}$ & 40 & $24.25 \pm 0.608$ \\
\hline 600 & $48.2 \pm 2.600 \mathrm{a}$ & $45.8 \pm 0.400 b$ & $26.1 \pm 0.451 \mathrm{c}$ & $22.6 \pm 0.800 \mathrm{~d}$ & 60 & $40.19 \pm 0.157$ \\
\hline 800 & $63.4 \pm 0.551 \mathrm{a}$ & $58.5 \pm 1.050 \mathrm{~b}$ & $32.0 \pm 0.400 \mathrm{c}$ & $29.6 \pm 0.751 d$ & 80 & $58.46 \pm 0.001$ \\
\hline 1000 & $80.3 \pm 0.300 \mathrm{a}$ & $70.1 \pm 0.600 \mathrm{~b}$ & $38.3 \pm 0.058 \mathrm{c}$ & $36.5 \pm 0.100 \mathrm{~d}$ & 100 & $73.71 \pm 1.048$ \\
\hline
\end{tabular}

${ }^{1}$ Concentrations

${ }^{2}$ Each value is the average of three analyses \pm standard deviation. The same letter do not differ significantly at $p<0.05$.

M1: Methanolic extract, first collection; M2: Methanolic extract, second collection; E1: Ethanolic extract, first collection; E2: Ethanolic extract, second collection; AA: Ascorbic acid 


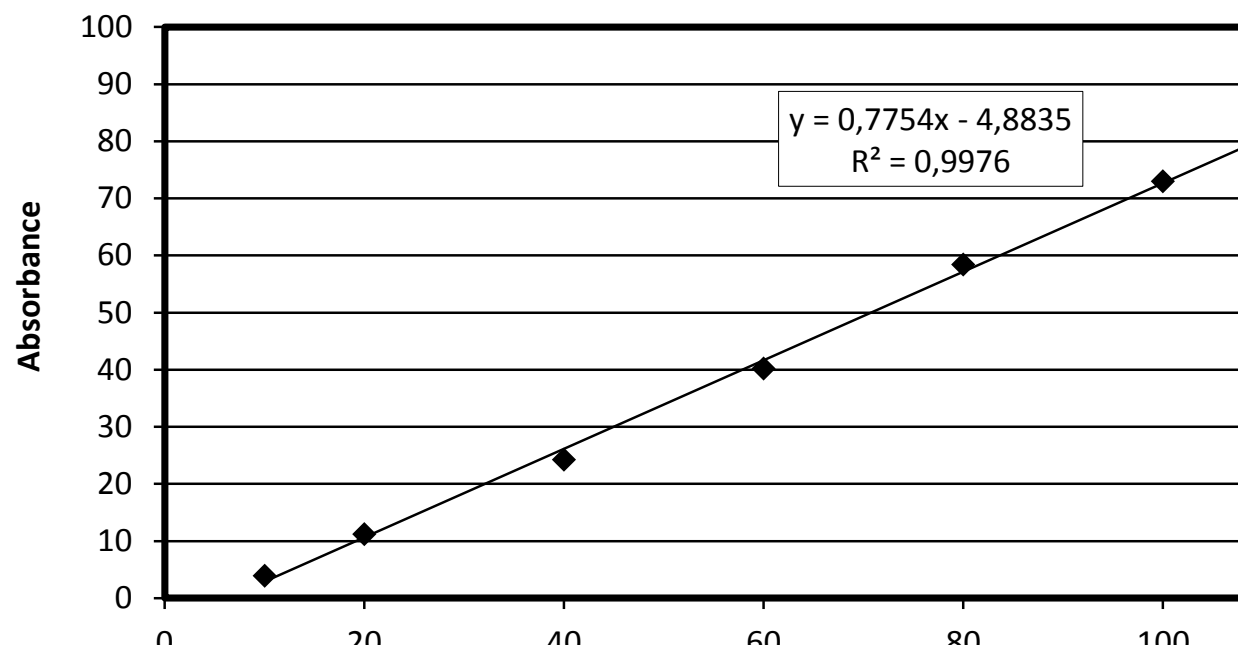

Figure 3. Standard calibration curve of ascorbic acid at concentration of $20,40,60,80$ and $100 \mu \mathrm{g} \mathrm{ml}^{-1}$. Spectrophotometric detection was at $517 \mathrm{~nm}$

Studies conducted in previous years have shown that $P$. feruleceae extracts have antioxidant activity at varying ratios (Kafash-Farkhad et al., 2013). Very high antioxidant activity was observed in some studies (Coruh et al., 2007), but very low activity was detected in some (Ahmed et al., 2011). Also, it has been reported that the various chemicals (flavonoids, alkaloids, terpenoids, phenolic compounds etc.) in the plant have high antioxidant activity (Sajjadi and Mehregan, 2003; Coruh et al., 2007). Contrary to this, the flavonoid, quercetin-3-0-glucoside, in the extract from aerial parts of the plant did not exhibit antioxidant activity in the study conducted by Razavi et al. 2009. According to the results of DPPH test in our study, all fruit extracts exhibited a slightly antioxidant activity. Many of the secondary metabolites such as alkaloids, essential oils, phenol and flavonoids synthesized by plants show large variations depending on the environmental conditions under which the plant grows. Temperature and light fluctuations promote the synthesis of antioxidants, bacterial infections promote the synthesis of phenolic and flavonoids (Baydar, 2013; Mammadov, 2014). All of this is the effort of plants to adapt to the environment they grow. Differences in synthesis of secondary metabolites in plants are possible, in view of the differences in collection sites and timing of collections, the part of the plant used, the growth stage of plant when collected and the methods of analysis etc. (Marotti et al., 1994; Coruh, 2007; Ahmed et al., 2011; Akhgara et al., 2011; Kafash-Farkhad et al., 2013). Similarly, the antioxidant properties of these extract were found to be used solvent, concentration and collection time dependent in our study. The variability in the total phenolic contents of extracts prepared using different solvents may be due to the different solubility of the phenolic compounds (Damyeh and Niakousari, 2016). Bioactive substances in plants show significant changes according to the collection time, organ and life cycle of the plant (Baydar, 2013). The effectiveness and quality of medicinal and aromatic plants depends on their chemical composition. On the other hand, there is a considerable effect of seasonal variation on the chemical composition and biological activities of plants (Soni et al., 2015). Flavonoids which are substances that give color to flowering plants are the most common group of phenolic compounds. Flavonoids are used to prevent tumor formation and diabetes, as antioxidants, antiinflammatory, anti-viral, anti-allergic, antimicrobial and enzyme inhibitory in medicine (Mammadov, 2014). Flavonoids are powerful antioxidants that protect the cells against antiradicals. Also, they 
prevent the growth of bacteria and viruses, and provide resistance against cancer formation and heart attack. Quercetin which is a chemical pigment commonly found in the various organs of many plants is a flavonoid and have a powerful antioxidant activity (Baydar, 2013). It was observed that there was positive correlation $(r=0.718)$ between total phenolic content and total flavonoid content. This correlation was not significant statistically. Also, correlation coefficients between DPPH, total phenolic content and total flavonoid content and total phenolic content were negatively associated with DPPH $(\mathrm{r}=-0.971, \quad \mathrm{P}<0.05$ and $\mathrm{r}=-0.608$, respectively) (Table 3 ).

Table 3. Correlation coefficients between DPPH, total phenolic content and total flavonoid content

\begin{tabular}{llll}
\hline & $\mathbf{1}$ & $\mathbf{2}$ & $\mathbf{3}$ \\
\hline 1. Total Phenolic Content & 1.000 & & 1.000 \\
\hline 2. Total Flavonoid Content & $0.718^{\mathrm{ns}}$ & $-0.608^{\mathrm{ns}}$ & 1.000 \\
\hline 3. DPPH & $-0.971^{*}$ & 2
\end{tabular}

${ }^{*} P<0.05$, ns: statistically insignificant

Some researchers support the association between phenolic compounds and antioxidant activity (Bendini et al., 2006; Dlugosz et al., 2006; Wojdylo et al., 2007), while the others argue that there is no direct relationship between these two parameters (Harish and Shivanandappa, 2006; Hassimotto et al., 2005; Abdelhady et al., 2011; Mammadov, 2014). In addition to phenolic compounds, other chemical compounds may be said to have an effect on antioxidant activity (Harish and Shivanandappa, 2006). Also, it has been stated that the flavonoid content of P. ferulaceae is not solely responsible for antioxidant activity and that there is no sufficient study on the detection of compounds responsible for antioxidant activity (Ahmed et al., 2011).

\section{CONCLUSION}

In this study, the DPPH radical scavenging activity, and amount of total phenolic and flavonoid compounds of the extracts from fruit of $P$. ferulaceae were analyzed.

\section{REFERENCES}

Abdelhady MIS, Motaal AA, Beerhues L, 2011. Total Phenolic Content and antioxidant activity of standardized extracts from leaves and cell cultures of three Callistemon species. American Journal of Plant Sciences, 2:847-850.

Acıkgoz N, Ilker E, Gokcol A, 2004. Biyolojik araştırmaların bilgisayarda değerlendirmeleri. Ege University Publication No:2, Izmir.

Ahmed J, Guvenc A, Kucukboyaci N, Baldemir A, Coskun M, 2011. Total phenolic contents and antioxidant activities of Prangos Lindl. (Umbelliferae) species growing in Konya province (Turkey). Turk J Biol.,35:353-360.
As known, collection time is an important factor affecting the quality of medicinal and aromatic plants. Therefore, the plants were collected at two different times (May and July) to see the variation between collection times, and effect of seasonal variation on the DPPH radical scavenging activity, and amount of total phenolic and flavonoid compounds of the extracts was evaluated in this study.

The findings from the analysis results demonstrated that the extracts of fruits collected at two different times exhibited a slightly antioxidant activity. However, the antioxidant properties of these extract were influenced by the solvent and concentration used, and the collection time of the fruits. According to the findings obtained from our study, we recommend collecting the fruit of P. ferulaceae in May. Detailed phytochemical analyzes are needed to fully understand the antioxidant capacity of this species.

Akhgara M, Pahlavanzadeh-Irana S, Lotfı-Anarıb P,Faghıhızarandıc A, 2011. Composition of essential oils of fruits and leaves of Prangos ferulacea (L.) Lindl. growing wild in Iran. Trends in Modern Chemistry, 1:1-4.

Arvouet-Grand A, Vennat B, Pourrat A, Legret P, 1994. Standardisation d'un extrait de propolis et identification des principaux constituants. J. de Pharmacie de Belgique, 49:462468.

Baser KHC, Ermin N, Adiguzel N, Aytac Z, 1996. Composition of the essential oil of Prangos ferulaceae (L.) Lindl. J. Essent. Oil Res., 8:297-298. 
Baser KHC, Ozek T, Demirici B, Duman H, 2000. Composition of essential oil of Prangos heyniae. H. Duman et M.F. Watson, a new endemic from Turkey. Flavour Fragrance Journal,15:47-49.

Baydar H, 2013. Tibbi ve Aromatik Bitkiler Bilimi ve Teknolojisi. Süleyman Demirel Üniversitesi, Ziraat Fakültesi, Yayın No:51.

Bendini A, Cerretani L, Pizzolante L, et al, 2006. Phenol content related to antioxidant and antimicrobial activities of Passiflora spp. extracts. European Food Research and Technology, 223:102-109.

Coruh N, Sagdicoglu Celep AG, Ozgokce F, 2007. Antioxidant properties of Prangos ferulacea (L.) Lindl., Chaerophyllum macropodum Boiss. and Heracleum persicum Desf. from Apiaceae family used as food in Eastern Anatolia and their inhibitory effects on glutathione-S-transferase. Food Chemistry, 100:1237-1242.

Damyeh MS, Niakousari M, 2016. Impact of ohmic-assisted hydrodistillation on kinetics data, physicochemical and biological properties of Prangos ferulacea Lindle. essential oil: Comparison with conventional hydrodistillation. Innovative Food Science and Emerging Technologies, 33: 387-396.

Dlugosz A, Lembas-Bogaczyk J, Lamer-Zarawsko E. 2006, Antoxid increases ferric reducing antioxidant power (FRAP) even stronger than vitamin C. Acta Pol. Pharm., 63:446-448.

Gezer K, Duru ME, Kivrak I, Tirkoglu A, Mercan N, Turkoglu H, Gulcan S, 2006. Free-radical scavenging capacity and antimicrobial activity of wild edible mushroom of Turkey. African Journal of Biotechnology, 5:1924-1928.

Guner A, Aslan S, Ekim T, Vural M, Babac MT, 2012. Türkiye bitkileri listesi (Damarlı Bitkiler). Nezahat Gökyiğit Botanik Bahçesi ve Flora Araştırmaları Derneği Yayını, İstanbul.

Harish R, Shivanandappa T, 2006. Antioxidant activity and hepatoprotective potential of Phyllanthus niruri. Food Chemistry, 95:180-185.

Hassimotto NMA, Genovese MI, Lajolo FM, 2005. Antioxidant activity of dietary fruits, vegetables, and commercial frozen fruit pulps. Journal of Agricultural and Food Chemistry, 53:2928-2935.

Kafash-Farkhad N, Asadi-Samani M, Rafieian-Kopaei M, 2013. A review on phytochemistry and pharmacological effects of Prangos ferulacea (L.) Lindl. Life Science Journal, 10:360367.

Mammadov R, 2014. Tohumlu Bitkilerde Sekonder Metabolitler. Nobel Akademik Yayıncılık Eğitim Danışmanlık Tic. Ltd. Şti. Yayın No:841.
Marotti M, Piccaglia R, Giovanelli E, Deans SG, Eaglesham E,1994. Effects of variety and ontogenic stage on the essential oil composition and biological activity of fennel (Foeniculum vulgare Mill.). Journal of Essential Oil Research, 6:57-62.

Mirzaei HH, Meshkatalsadat MH, Soheilivand S, 2007. Determination of essential oil composition of Prangos acaulis (DC) Bornm obtained by hydrodistillation and supercritical fluid extraction methods. Journal of Applied Sciences, 7:25352538 .

Mneimne M, Baydoun S, Nemer N, Apostolides NA, 2016. Chemical composition and antimicrobial activity of essential oils isolated from aerial parts of Prangos asperula Boiss. (Apiaceae) growing wild in Lebanon. Medicinal\&Aromatic Plants, 5:3. 5:242.doi.10.4172/2167-0412.1000242.

Ogut S, 2014. Importance of natural antioxidants. Journal of Adnan Menderes University Agricultural Faculty, 11:25-30.

Razavi SM, Zahri S, Zarrini G, Nazemıyeh H, Mohammadı S, 2009. Biological activity of quercetin-3-O-glucoside, a known plant flavonoid. Russian Journal of Bioorganic Chemistry, 35:376-378.

Razavi SM, Nazemiyeh H, Zarrini G, Asna-Asharii S, Dehghan $\mathrm{G}, 2010$. Chemical composition and antimicrobial activity of essential oil of Prangos ferulaceae (L.) Lindl from Iran. Nat Prod Res., 24:530-533.

Sajjadı SE, Mehregan I, 2003. Chemical composition of of the essential oil of Prangos asperula Boiss. subsp. haussknechtii (Boiss.) Herrnst. et Heyn fruits. Daru, 11:79-81.

Shirazi OU, Khattak MAK, Shukri NAM, MN Nasyriq A, 2014. Determination of total phenolic, flavonoid content and free radical scavenging activities of common herbs and spices. Journal of Pharmacognosy and Phytochemistry, 3:104-108.

Singleton VL, Orthofer R, Lamuela-Raventos RM, 1999. Analysis of total phenols and other oxidation substrates and antioxidants by means of Folin-Ciocalteu reagent. Methods Enzymol, 299:152-178.

Soni U, Brar S, Gauttamm VK, 2015. Effect of seasonal variation on secondary metabolites of medicinal plants. International Journal of Pharmaceutical Sciences and Research, 6:36543662 .

Tirzitis G, Bartosz G, 2010. Determination of antiradical and antioxidant activity: basic principles and new insights. Acta Biochimica Polonica, 57:139-142.

TUBIVES, 2011.Turkish Plants Data Servicehttp//www.tubives. com. (Erişim tarihi: 01.05.2017).

Wojdyło A, Oszmian J, Czemerys R, 2007. Antioxidant activity and phenolic compounds in selected herbs. Food Chemistry, 105: 940-949. 